\title{
Rudolf Bultmann se verstaan van vryheid
}

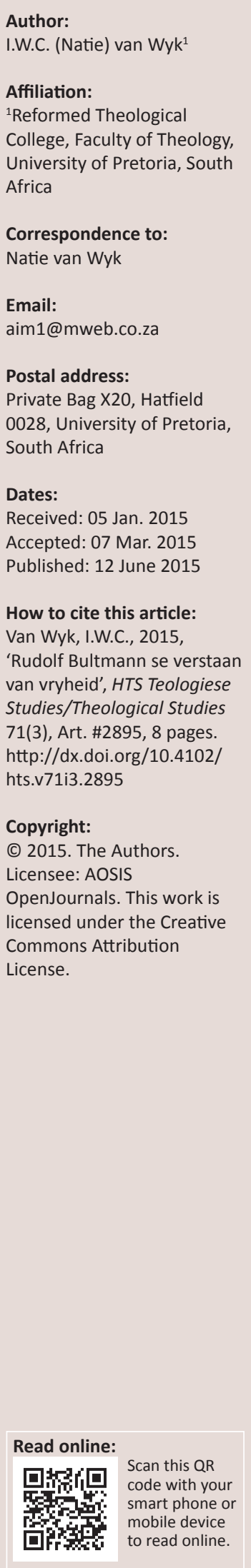

Rudolf Bultmann's understanding of freedom. This article is a reworked version of a paper delivered at a symposium on the life and work of Rudolf Bultmann who was born on the 20th August 1884. The article deals with Bultmann's understanding of Christian freedom. Three articles of Bultmann on freedom are presented and evaluated: (1) Grace and freedom - 1948; (2) The importance of freedom for European culture - 1952; (3) The idea of freedom in antiquity and Christianity - 1959. The relevancy of Bultmann's theology is explained to present-day Afrikaans speaking people. Bultmann's theology is not only presented as relevant, but also as an important guideline for Reformational thinking. Bultmann is presented as a credible Lutheran theologian. His explanation of the doctrine of justification remains helpful in a context of constant self-justification. Some critical remarks are made from a Reformed perspective.

\section{Inleiding}

'Vryheid' is een van die belangrikste begrippe waarmee die Reformatoriese teologie werk (vgl. Huber 2007; Körtner 2010:51-60; Moltmann [1997] 1999:191-208; Sauter 1986). Dit was daarom vanselfsprekend dat Martin Luther en Philipp Melanchthon reeds vroeg in die Reformatoriese stryd hieroor sou skryf. Luther het in sy geskrif Oor die vryheid van 'n Christenmens (1520), ${ }^{1}$ aanvanklik gepubliseer in Latyn (Tractatus de libertate Christiana =1520a) en kort daarna in Duits vertaal en verwerk (Von der Freiheit eines Christenmenschen $=$ [1520b] 2012), sy verstaan van die Christelike vryheid soos volg saamgevat:

Sodat ons grondig mag weet wat 'n Christenmens is en hoe dit met sy vryheid gesteld is, wat vir hom deur Christus verwerf en aan hom geskenk is, waarvan die apostel Paulus so baie skryf, wil ek die volgende twee stellings opstel: ' $n$ Christenmens is ' $n$ vrye heer oor alle dinge en niemand se onderdaan nie. 'n Christenmens is 'n diensbare kneg van alle dinge en aan almal onderdanig. ${ }^{2}$ (WA 7, 20-21, 2; 2012:280; my vertaling)

Vanuit bogenoemde paradoksale stelling het Luther 'n paradoksale antropologie ontwikkel wat neerkom op vryheid in geestelike dinge en knegskap in wêreldlike dinge. Sy verstaan van geloof, menswees en moraliteit word dan aan die einde van hierdie geskrif soos volg saamgevat:

Uit alles [wat gesê is] volg die volgende konklusie; dat 'n Christenmens nie in homself lewe nie, maar in Christus en sy naaste: In Christus deur die geloof, in die naaste deur die liefde. Deur die geloof vaar hy opwaarts na God, van God vaar hy weer afwaarts deur die liefde en bly dan altyd in God en die Goddelike liefde. Dit is, soos wat Christus in Johannes 1:51 sê: 'Julle sal nog die hemel oop sien staan en die engel op- en afstyg bokant die Seun van die Mens.' Kyk, dít is die regte, geestelike vryheid, wat die hart van alle sonde, wette en gebooie vrymaak. Dit oortref alle andere vryhede wat daar in die hemel en die aarde mag wees. Mag God gee dat ons dit reg verstaan en daaraan vashou! Amen. ${ }^{3}$ (Luther WA 7, 38, 6-15; 2012:314; my vertaling)

Dit is minder bekend dat Melanchthon ook van die staanspoor oor die tema vryheid geskryf het. Hy het reeds in die eerste uitgawe van sy Loci Theologici (1522) 'n hele hoofstuk aan hierdie tema afgestaan. Teen die tyd dat hierdie werk in 1553 die eerste keer in Duits gepubliseer is (Melanchthon [1553] [2002] 2010), het die gedeeltes oor die vryheid al 15 bladsye beslaan (vgl. veral [1553] [2002] 2010:310-315). Melanchthon argumenteer dat daar vier vlakke van vryheid vir 'n Christen bestaan. Die eerste vlak het te make met die vryheid wat deur die Seun van God bewerk is - met ander woorde ons verlossing. Die tweede vlak het te make met die werk van die

\section{Kyk Jüngel ([1978] 2000) vir'n volledige kommentaar op hierdie teks.}

2.Das wir grundlich muegen erkennen / was eyn Christen mensch sey / vnd wie es gethan sey / vmb die freyheyt / die yhm Christus erworben vnd geben hatt / dauon Sankt Paulus viel schreybt / will ich setzen / dysze zween beschlusz: Eyn Christen mensch ist ein freyer herr / ueber alle ding / vnd niemandt vnterthan. Eyn Christen mensch ist eyn dienstpar knecht aller ding vnd yderman vnterthan.

3.Aub dem allenn folget der beschlusz / das eyn Christen mensch lebt nit ynn yhm selb / sondern ynn Christo vnd seynem nehstenn / ynn Christo durch den glauben / ym nehsten / durch die liebe (oder er ist kein Christ/) durch den glauben feret er (wird er hinauf gerissen) vber sich yn gott / ausz gott feret er (gleitet er) widder vnter sich durch die liebe / vnd bleybt doch ymmer ynn gott vnd gottlicher liebe / Gleych wie Christus sagt Johan. 1. [51]. Ihr werdet noch sehen den hymell offen stehn / vnd die Engell auff vnd absteygenn vbir den Sun des menschen. Sihe, das ist / die rechte / geystliche / Christliche freyheyt / die das hertz frey macht / von allen sundenn / gesetzen / vnd gepotten / wilch alle andere freyheyt vbirtrifft / wie der hymell die erdenn / Wilch geb vns gott recht zuuorstehen vnd behaltenn / AMEN. 
Heilige Gees. Die Gees skenk aan ons vreugde aangesien Hy ons oortuig dat ons deur die geloof alreeds aan die ewige lewe deel het. Die besef van die teenwoordigheid van God in ons, is ' $n$ diep ervaring van menslike vryheid. Melanchthon ([1553] [2002] 2010) vat hierdie twee vlakke van vryheid saam deur te sê:

Elkeen moet nou bedink hoe hoog en groot die genade en gawe van hierdie vryheid is: redding van sonde, van God se toorn, van ewige straf, genadige vergewing van sonde, geregtigheid, God se teenwoordigheid in ons, troos, versterking hulp en beskerming in alle gevare - en dít alles om Christus ontwil uit genade. $^{4}$ (bl. 311; my vertaling)

Die derde vlak van vryheid het te make met die wet van Moses, soos dit gestalte kry in die wette en seremonies van die staat. Melanchthon ([1553] [2002] 2010:312) wys daarop dat die Christelike vryheid daarin bestaan dat ons vry is teenoor die wette en die staat. Christene is gehoorsaam aan die wet van Christus, met die gevolg dat hulle nie elke wet en verordening slaafs moet navolg nie. In vryheid, kan en moet hulle hul van wette distansieer wat nie met die evangelie versoenbaar is nie - met die wete dat hulle die gevolge sal moet dra. Om hierdie rede lê hy ([1553] [2002] 2010:314) die riglyn neer: Omnis lex obligat ad obedietiam vel ad poenam voluntariam / Elke wet verplig tot gehoorsaamheid óf tot vrywillige boetedoening (as gevolg van die oortuiging dat ongehoorsaamheid gebiedend is). Nogtans moet daar besef word dat Christene vry is van die morele wet van Christus in soverre dit ons regverdiging en verdoemenis aangaan, maar nie in soverre dit ons gehoorsaamheid raak nie (quo ad iustificationem et ad condemnationem, non quo ad obedientiam). Met ander woorde: Van ons word wetsgehoorsaamheid verwag (maar ons is vry van 'n slaafse navolging), maar op grond van die geskenkte vryheid van Christus, bepaal dit nie ons regverdiging en of verdoemenis nie (vgl. Melanchthon [1553] [2002] 2010:314). Die vierde vlak van vryheid het te make met die vryheid teenoor die kerkorde en menslike ordinansies. Hiermee bedoel hy nie dat lidmate nie die kerkorde moet gehoorsaam nie, maar dat gehoorsaamheid daaraan nie tot jou verlossing bydra nie (vgl. [1553] [2002] 2010:315).

Rudolf Bultmann het as toegewyde Lutheraan (Lohse 1974), op voetspoor van sy geestelike vader(s), die Pauliniese regverdigingsleer, as leer oor die vryheid, in 1948 vir sy eie generasie verduidelik. In die daaropvolgende jare het Bultmann meermale na die vryheidstema teruggekeer om die kultureel politieke en geesteshistoriese belangrikheid van die Christelike vryheidsverstaan te verduidelik. Ons gee aandag aan drie belangrike artikels.

\section{Genade en vryheid (1948)}

Die probleem oor die verhouding tussen Goddelike genade en menslike vryheid moet telkens nuut bedink word. Minstens Filippense 2:12-13 gee hiertoe aanleiding: 'Julle moet julle eie

4. Nu bedenk ein ieder, wie hohe, grosse gnaden und gaben dise freyheit in sich fasset errettung von sunden, von gottes zorn, von ewiger straff, gnedige vergebung der sunden, gerechtikeit, gottes gegenwertikeit in uns, trost, sterkung, hulff und schutz in aller fehrlikeit - und dies alles umb des herrn Christi willen aub gnaden'. verlossing met vrees en bewing bewerk, want dit is God wat in julle werk, beide om te wil en om te werk vir sy welbehae'. Indien die mens totaal afhanklik is van dít wat God in hom bewerk, hoe kan daar dan nog van sy eie vrye doen en beslissing sprake wees? Word geloof en ongeloof in gelyke mate deur God bewerk, is die vraag of die mens dan nie alle verantwoordelikheid verloor of hy glo of nie glo nie. Paulus leer dat die mens alleen deur die geloof, sonder die werke van die wet, geregverdig word (Rom 3:28). Die geloof word gerig op die genade van God soos geopenbaar in Christus. Sonder verdienste word ons deur genade geregverdig vanweë die verlossingswerk van Jesus Christus (Rom 3:24). 'Julle is inderdaad uit genade gered, deur geloof. Hierdie redding kom nie uit julleself nie; dit is 'n gawe van God' (Ef 2:8). Die probleem lê natuurlik in die dubbelslagtigheid van die antitese. Nie werke nie, maar geloof! Nie werke nie, maar genade! Die vraag is: Wat is die verhouding tussen geloof en genade? Is geloof die voorwaarde vir genade? Indien wel, sou geloof ' $n$ werk wees. Die probleem raak net erger wanneer onthou word dat geloof ook gehoorsaamheid is (Rom 1:5), en daarom weer op 'n werk kan neerkom. Om antwoorde op hierdie vraagstellings te gee, bied Bultmann 'n aktuele uitleg van die 'Lutherse' regverdigingsleer aan (vgl. Jüngel [1998] 1999 vir 'n onlangse Lutherse uitleg van die regverdigingsleer).

Hy begin met 'n verklaring van dít wat Paulus 'werk' noem. Hy wys daarop dat die gedagte dat die gelowige sonder die werke van die wet, deur geloof, uit genade geregverdig word, nie van die gedagte van 'roemloosheid' losgekoppel moet word nie. Paulus (Rom 3:27-28) openbaar die insig dat redding uit genade en geloof die mens van roemsugtigheid bevry. Die werke van die wet en menslike roem loop volgens Paulus hand aan hand. Trouens, menswees sentreer rondom selfroem. Elke mens en nasie wil op die een of ander wyse op iets roem. Die Jood wil dit doen met behulp van werke, terwyl die Griek dit met behulp van wysheid wil doen. Hierdie roem waarna mense op soek is, het ten diepste te make met die soeke na 'geregtigheid'. Die 'geregtigheid' wat hier ter sprake is, is nie morele geregtigheid nie, maar geregtigheid wat uitgespreek moet word - en wel deur God. Toegesproke geregtigheid het te make met die mens se eer en menswaardigheid - dít wat hom uiteindelik as mens laat geld (Geltung). Hierdie 'geldingsbehoefte' of 'drang na erkenning' (Geltungsbedürfnis) is hedendaagse woorde vir Paulus se gedagtes van 'eer' en 'roem' (Bultmann [1948] [1952] 1968b:151). Volgens Bultmann is die geldingsdrang altyd 'n drang na gelding voor God - gelding voor die laaste en hoogste instansie wat 'n oordeel oor my lewe kan uitspreek. Om deur God regverdig verklaar te word, om deur sy oordeel bevestiging van jou menslike waardigheid te ontvang, is belangrik, aangesien ons as mense gedurigdeur onseker is van ons menslike waarde. Die behoefte om voortdurend deur ander mense geprys te word, het met die feit te make dat ons ten diepste onseker is oor ons eie menslike waardigheid. Bultmann ([1948] [1952] 1968b:152) is oortuig dat Paulus wou sê: Ons kan nie deur ons werke geregverdig word nie, óf ons kan nie verwag dat God op grond van ons doen en late 'n positiewe oordeel oor ons 
lewens uitspreek nie - ons moet glo dat Hy dit op grond van sy genade sal doen.

Wat beteken dit om uit die geloof geregverdig te word? Vir Bultmann ([1948] [1952] 1968b:152) is die geloof die houding waardeur die geldingsdrang onderdruk word (Geltungsdrang entgegengesetzte Haltung), die radikale prysgawe van die selfroem, óf die wil om jouself te laat geld op grond van jou eie prestasies. Geloof is die insig en aanvaarding (Erkenntnis) dat die menslike gelding, of reg op bestaan, slegs in die geloof as geskenk aanvaar kan word. Wat aan ons geskenk word en in die geloof ontvang word, is nie iets waarop geroem kan word nie. Binne hierdie lewensbenadering is daar nie ruimte vir eersugtigheid nie (1 Kor 4:7).

Paulus weet egter dat ons as mense nie sonder erkenning (Geltung) kan bestaan nie - die erkenning wat ander aan ons toedig en waarin ons ons vreugde vind. As sodanig is erkenning nie iets pervers nie. Die misverstand tree egter dáár na vore waar mense dink dat hulle erkenning kan afdwing deur ander positief te laat oordeel oor hulle menslike prestasies, en om hierdie oordele dan as maatstaf van hulle menswaardigheid te maak. Erkenning word pervers wanneer ons gunstige oordele van ander, en selfs van God, wil afdwing op grond van dít wat ons menslik bereik het. Ons moet ons broodnodige erkenning eerder as geskenk ontvang, sodat ons eerder uit God se genadige oordeel kan lewe ([1948] [1952] 1968b:153).

Bultmann ([1948] [1952] 1968b:153) wys (as vroegtydige vermaning) daarop dat 'n opdringende geldingsdrang vir ander onuithoubaar is. Wie voortdurend op soek is na erkenning en verering gaan dit juis misloop. Ons wêreld is vol naywer en jaloesie en mense gee nie graag aan ander erkenning nie - veral nie aan diegene wat kruipend en manipulerend daarna vra nie. Aan die ander kant misluk die grootdoenerige mens gereeld en die gekoggel deur ander kan hom maklik in depressie laat verval. Dit is daarom beter om by voorbaat eerder vanuit die genade te lewe.

Hierdie eenvoudige oorgawe aan God se genade in die prysgawe van die wil om jouself te laat geld, is geloof. En God se genade is niks anders nie as sy goedheid om die mens te laat geld, nét soos hy is; wat nie verlang dat hy homself in 'n beter, geldingswaardige [wese] verander nie, maar deurdat Hy hom aanneem, soos hy is, tot 'n beter [mens] maak. ${ }^{5}$ (Bultmann [1948] [1952] [1968b:153])

Indien geloof oorgawe aan God se genade is, in hoeverre is dit geloof in Christus? Bultmann ([1948] [1952] [1968b:154]) verduidelik dat sy verstaan van geloof alles met Christus te make het. Geloof in Christus is egter nie die vir-waarhou van dogmatiese uitsprake oor Christus nie. Hy sluit by Melanchthon ([1521] [1993] 1997:22) aan wat gestel het: 'Christum cognescere hoc est: beneficiae ius cognescere, non eius naturas, modos incarnationis intueri.' Wat is hierdie 'weldade

5. Diese schlichte Hingabe an Gottes Gnade im Verzicht auf das Geltenswollen ist der Glaube. Und Gottes Gnade ist nichts anderes als seine Güte, die den Menschen so gelten läbt, wie er ist; die nicht verlangt, dab er sich zu einem besseren, so gelten läbt, wie er ist; die nicht verlangt, dab er sich zu einem besseren,
geltungswürdigeren mache, sondern ihn dadurch, dab sie ihn nimmt, wie er ist, zu einem neuen, besseren mach' ([1948] [1952] 1968b:153). van Christus' egter? Dit bestaan daarin dat sy gestalte en werk, soos wat ons dit in die prediking leer ken, ons van die waan bevry dat ons uit eie krag erkenning by God kan afdwing. Hy is die geskenk van God aan die wêreld waarin die geskenkte genade van God duidelik blyk - voordat ons nog daaraan kan dink om iets vir hierdie genade te doen. Hierdie genade wat deur die kruis aan ons bekend gemaak is, is vir Jode en Grieke onsin. Die onsin lê daarin dat niemand iets sal oorhou om op te roem nie, sou hulle in die geloof die kruis omarm (1 Kor 1:1819; Gal 6:14). Vir die gelowige beteken dit egter bevryding bevryding van die dwang en las tot selfregverdiging.

Die volgende vraag wat Bultmann ([1948] [1952] 1968b:155) beantwoord, is of die geloof as oorgawe aan die genade van God in Christus ook tegelyk gehoorsaamheid kan wees. Volgens Bultmann is hier geen spanning nie, aangesien gehoorsaamheid juis neerkom op die knakking van menslike trots. Die mens wil nie wat vir hom wesenlik belangrik is (naamlik sy selfregverdiging) prysgee nie. Hy wil voortgaan met sy eie projek. Gehoorsaamheid aan God se projek beteken dat die mens sy eie projek moet prysgee - en om só van sy eie trots afstand te doen. In die lig hiervan kan Paulus verstaan word wanneer hy sê dat wat vir hom aanvanklik wins was, nou nie meer is nie, aangesien hy sy reg op menswees te danke aan die geregtigheid wat Christus vir hom bewerk het (Fil 3:7-9). Paulus se bekering het niks te make gehad met sy berou oor die verkeerdhede in sy lewe nie, maar met die prysgawe van alles waarop hy trots was. In hierdie lig kan verstaan word dat geloof gehoorsaamheid is aan dít wat aangaande Christus verkondig word.

Om jouself aan Christus prys te gee en om van jou eie trots afstand te doen, is nie maklik nie. Hiervoor benodig 'n mens God se genade - en op sy genade kan slegs vertrou word (Rom 4:17). Dit is dus vanselfsprekend dat gehoorsaamheid en vertroue met mekaar verband hou. Vertroue het nie te make met die kragdadige wil om iets te doen nie, maar die bereidwilligheid om voor God te buig en om sy genade te aanvaar. Geloof is nie 'n algemene Godsvertroue nie, maar die radikale oorgawe aan God se wil, wat ek nie ken voordat dit geskied nie - soos Luther na aanleiding van Romeine 8:26 gesê het: 'Semper ita fit, ut opus nostrum intelligamus, antequam fiat, Dei autem opus non intelligimus, donec factum fuerit.' Hierdie gehoorsaamheid en vertroue omvattende geloof is die beslissing van die mens vír of téén God - en in hierdie sin is geloof ook 'n daad. Bultmann ([1948] [1952] [1968b:156]) verduidelik dan dat geloof nie ' $n$ werk is nie, maar wel' $n$ daad. Geloof doen afstand van werke, maar neem daadwerklik ook beslissings - beslissings oor waarop ek ten diepste kan vertrou.

Op hierdie punt keer Bultmann terug na die probleem van genade en vryheid - wat hy meen reeds opgeklaar is. Ek stel hom self ([1948] [1952] [1968b]) aan die woord:

Die geloof is as vrye daad van beslissing, oorgawe aan God se genade - in die radikale sin dat hy nie na homself kyk nie, nie teenoor homself rekenskap kan aflê nie en nie oor homself kan roem nie. Geloof is die voorwaarde vir die ontvang van genade; nogtans nie só dat die gelowige kan meen dat hy aan hierdie voorwaarde voldoen het en daarom op die genade aanspraak 
kan maak nie. Dít sou die geloof juis ten gronde rig ... Daardeur sou die geloof sigself ophef en tot ' $n$ werk verander word. Geloof is juis daarin egte daad, dat dit daarop bedag is, om nie sigself [as doenende mens] te verdank nie, maar die genade wat hom toebedeel word [aan te neem]. Die gelowige weet dat hy in die ontmoeting van die genade uitverkies is. ${ }^{6}$ (bl. 157; my vertaling)

Die groot probleem lê egter by hierdie paradoks, naamlik dat geloof 'n vrye daad is, maar tegelyk ook weet dat dit reeds gekies is. Hoe is albei tegelyk moontlik? Dit is moontlik tensy 'n mens op 'n predestinasieleer wil staatmaak. My beslissing vir die geloof is my eie daad. Dit kan nie gepredestineer wees nie, aangesien dit dan nie ' $n$ beslissing is nie en daarom nie geloof kan wees nie. Geloof is slegs geloof wanneer dit beslissing is en ' $n$ beslissing is slegs beslissing wanneer dit in vryheid gedoen word. Volgens Bultmann ([1948] [1952] [1968b:158]) weet die geloof dat hy glo wanneer hy uit vryheid ten gunste van God beslis - dat hy toelaat dat God aan hom handel. Hy weet van God se handeling slegs in soverre hy glo - en hy het nie die moontlikheid om buite die geloof oor God se handeling te spekuleer nie. Die gelowige weet egter dat, in sy daad van geloof, hy uitverkies is. Uitverkiesing kan nie buite die geloof om 'waar' wees nie. Vryheid en genade bly dus 'n paradoksale eenheid.

Wanneer Bultmann alles tot samevatting bring, stel hy dat die geloofsbeslissing die radikale vryheid van die mens bevestig deurdat die gelowige homself bevry van alles wat hom sekerheid mag bied en homself alleenlik verlaat op God se genade. Menslike vryheid en Goddelike genade gaan dus hand aan hand. Radikaler gestel: Dit is die genade van God wat egte vryheid moontlik maak. Egte vryheid is vryheid van jouself en nie net vryheid van die gedetermineerdheid van die wil nie [1948] [1952] 1968b:160). Vryheid gebore uit die genade van God is nie 'n afgehandelde toestand nie, maar is 'n geskenk wat weer en weer gegryp moet word. Ek moet weer en weer besluit of ek vanuit die genade wil lewe - en só ware vryheid wil belewe. Hierdie beslissing sal egter aan my geskenk wordek moet dit net aanvaar ([1948] [1952] 1968b:161).

\section{Kritiese waardering \\ Positief}

Die mens se behoefte aan erkenning het die afgelope jare weer sterk na vore gekom. Die gewilde 'LinkedIn' bevredig blykbaar akademici en ander professionele persone se behoeftes aan erkenning. Bultmann se betoog rondom die regverdigingsleer raak hierdie hele bedrywigheid ten diepste. Om positiewe oordele van kollegas af te smeek, en om hierdie oordele dan aan te wend om 'n positiewe selfbeeld op te bou en selfs aardse geluk te probeer vind, is 'n verval in die roemstrewe van die sondige mens. Bultmann kan ons leer om

6. Der Glaube ist als freie Tat der Entscheidung die Hingabe an Gottes Gnade in dem radikalen Sinne, daB er auch nicht auf sich selbst blicken, sich nicht von sich selbst
Rechenschaft ablegen kann, sich nicht seiner selbst rühmen kann. Der Glaube ist Rechenschaft ablegen kann, sich nicht seiner selbst rühmen kann. Der Glaube ist
die Bedingung für den Empfang der Gnade; jedoch nicht so dab der Glaubende die Bedingung für den Empfang der Gnade; jedoch nicht so dab der Glaubende
meinen könnte, er habe diese Bedingung erüllt und könne daraufhin auf die Gnade Anspruch machen. Alles dies würde ja den Glauben gerade zunichte machen ... Damit hätte der Glaube sich selbst aufgehoben und wäre zum Werk geworden. De Glaube ist gerade darin echte Tat, dab er sich bewubt ist, nichts sich selbst, sondern alles der ihm begegnenden Gnade zu verdanken. Der Glaubende weib sich durch die Begegnung der Gnade erwählt' ([1948] [1952] 1968b:157). nie vanuit die oordele van ons medemens te lewe nie, maar om ons eerder te verlaat op die genadige oordeel van God in Christus. By Bultmann kan ons leer dat 'geregtigheid' of die reg op bestaan nie verdien kan word deur die aanhoudende uitbreiding van 'n lys van gemanipuleerde positiewe oordele deur ander oor ons menswees nie. Bestaansreg word in dankbaarheid as genadegeskenk in die geloof aanvaar.

\section{Leemte}

Bultmann sal aanvoer dat die vryheid wat deur God se vryspraak geskenk word, gebruik moet word om die naaste in liefde te dien. Die jammerte is dat Bultmann meestal huiwerig was om klem te lê op die plig van die vrygespreekte Christen om diensbaar teenoor die naaste te wees. Dit is egter te verstane dat hy, as gevolg van die oorloë, vertroue in die wil en goedheid van selfs die toegewyde Christen verloor het. Dit bly egter noodsaaklik dat ons onsself weer herinner wat Luther in sy vryheidsgeskrif (WA 7, 21, 1-4) op grond van 1 Korintiërs 9:19, Romeine 13:8 en Galasiërs 4:4 oor die Christelike vryheid gesê het. Hy het gestel dat 'n Christen vanuit die vryheid lewe, maar dat die vryheid hom tot diensbaarheid verplig. Hiermee wou Luther bo alle twyfel stel dat 'n vrygespreekte Christen, in liefde, diensbaar is aan sy naaste. Bultmann self kan nie van koudheid teenoor menslike leed beskuldig word nie. Van kindsdae af het hy Jode gehelp en bygestaan in hulle verontregting. Sy verbintenis met Leonhard Frank, Hans Jonas en Hannah Arndt is 'n aangrypende verhaal van Christelike naasteliefde (vgl. Hammann [2009] 2012:275-295). My punt is egter dat dit nodig bly om aanhoudend daarop te hamer dat die genade wat uit die regverdiging voortspruit nie goedkoop genade is nie. Genade en liefde, geloof en werke bly onlosmaaklik verbonde - ten spyte van die primaat van die geloof teenoor die werke (vgl. Bayer 1995; Jüngel 1990; [1998] 1999:227-234; [1978] 2000:152-157). Selfs die filosoof Baruzzi (1993:109-115) meen dat Paulus se verstaan van vryheid onlosmaaklik met die gedagte van naasteliefde saamhang). Ons, as Christene in die Gereformeerde (Reformierte) tradisie (veral soos dit by Karl Barth na vore tree), beklemtoon dat die vryheid van die geloof, vryheid is wat oorgaan tot dade. In vryheid doen die gelowige wat van hom as vrye wese verwag word. Vryheid is daadwerklike vryheid (vgl. Laube 2012), en na ons mening word hierdie perspektief nie genoegsaam deur Bultmann (minstens in hierdie artikels) uitgewerk nie.

\section{Die betekenis van die vryheidsgedagte vir die Europese kultuur (1952)}

Ná die Tweede Wêreldoorlog het die Duitsers diepsinnig nagedink oor die Europese erfenis en tradisie. Bultmann vra in 1952 wat die 'hoogste goed' is wat hierdie kultuur opgelewer het. Volgens hom is dit die 'idee van vryheid' wat sy oorsprong by die Grieke gehad het. Die filosofiese en teologiese weergawes van vryheid het bygedra tot die hoogtepunte, maar ook tot die laagtepunte van die Europese geskiedenis ([1952] 1968a:274-276). 
Die Griekse idee van vryheid het te make met die vryheid van die burger binne die samelewing. Hierdie konsep van vryheid het dus ten diepste met die stryd om die wet te make. 'Innerlike onafhanklikheid' soos die Stoa dit bepleit het, het dus neergekom op vryheid teenoor die waardestelsel van die gemeenskap - 'n edele, adellike houding dus; 'n houding wat uitgestyg het bokant die algemene, onnadenkende burgerlike moraal (Bultmann [1952] 1968a:276-277).

Die Oerchristendom, by name Paulus, het die vryheidsbegrip by die Hellenisme oorgeneem, maar daaraan 'n nuwe inhoud gegee. Hy het wel hier en daar (1 Kor 3:22; 6:12) met die Stoa saamgestem dat vryheid, vryheid teenoor en van die wêreld moet wees. Vryheid was vir hom egter veel méér as dít. Die kernverskil is dat vryheid vir die Grieke te make het met die denke van die individu, terwyl dit vir die Christelike geloof te make het met die histories (geschichtlich) eksisterende ek en sy konkrete lewensbeslissings, waarmee hy bokant die noodlot (Schicksal) kan uitstyg. Die probleem is egter dat die mens die somtotaal van sy beslissings is, en daarom nie vry kan wees nie, omdat hy 'n gevangene van sy eie verlede is. Hy is eers vry wanneer hy van die mag van sy eie verlede, sy sonde, bevry word - en dít word deur die vergewing en genade van Christus bewerkstellig. Vryheid is dus 'n openheid vir die toekoms - 'n openheid om dáár weer nuwe beslissings te maak ([1952] 1968a:277-278). Christelike vryheid is vir Bultmann vryheid van die persoon, wat nie 'n kwaliteit is nie, maar 'n gebeure wat hom telkens kan voltrek. Vryheid is daarom slegs 'n moontlikheid, aangesien dit van die menslike beslissing afhang vir realisering. Die probleem van vryheid begin vir die Christen waar dit vir die Stoa ophou. Vir die Stoïsynse filosoof is vryheid 'n vanselfsprekendheid aangesien die denkende mens bloot die wette van die verstand moet volg. Die Christen twyfel of die mens hoegenaamd vry kan wees, aangesien hy nie heer van sy eie beslissings is nie (Bultmann [1952] 1968a:279).

Wat Bultmann interesseer, is die vraag hoe die konsep van vryheid ontwikkel en bygedra het tot die Europese krisis. Volgens hom is die vryheidsideaal losgekoppel van sy Griekse en Christelike wortels, met die gevolg dat dit verword het tot ongebonde menslike subjektiwiteit, wat uitloop op die relativering van waarheid in wetenskap, etiek en godsdiens. Hierdie subjektivering hou verband met die moderne idee van vryheid wat ontwikkel het uit die strewe na vryheid teenoor die kerklike leertradisie. Die obsessiewe begeerte om vry te wees van die leeroutoriteit van die kerk het bygedra tot die individu se aanspraak dat hy die waarheid self kan poneer. Die gedagte dat vryheid ongebondenheid behoort te wees, het die weg geopen vir die onmenslikhede van die 20ste eeu. Bultmann ([1952] 1968a:281-282) wys dan daarop dat ander gelyklopende prosesse natuurlik ook tot hierdie katastrofes bygedra het, soos die ontwikkeling van die natuurwetenskap en tegniek, die historiese relativisme (wat uitgemond het in die nihilisme) en die angs vir egte vryheid wat neerkom op die angs vir die onsekerheid van beslissingsvryheid (met die gevolglike oorgawe aan die groter magte van die geskiedenis soos politieke strominge).
Bultmann ([1952] 1968a:283-284) argumenteer dat die verlore gaan van die Griekse en Christelike wortels van die vryheidsidee die volgende twee gevare inhou: (1) Die terugval op ' $n$ bepaalde fase van ons tradisie en (2) die oortuiging dat die willekeur met politieke mag gedemp moet word. Volgens Bultmann kan tradisie nie gekanoniseer word nie; dit kan slegs verder uitgebou word. Om maghebbers aan te moedig om hulle mag uit te bou, open die weg vir 'n volgende oorlog. Wanneer die individu sy verantwoordelikheidsgevoel prysgee en van die staat verwag om vir hom te sorg, vervaag 'n paar ander Europese waardes soos die idee van 'geskenk', die houding van 'dankbaarheid', die 'rus om te besin' en die 'vreugde om fees te vier en te speel' ([1952] 1968a:286-287). Bultmann tree dus 'apologeties' in vir die Christendom spesifiek vir die Lutherse gestalte daarvan (vgl. [1952] 1968a:291). Hy is oortuig dat slegs die Christelike geloof die mens kan help om sy menslikheid te bewaar - en hy bewaar sy menslikheid deur die vryheid van die geloof te bewaar.

\section{Kritiese waardering Positief}

Bultmann wys tereg daarop dat vryheid nie net misbruik kan word nie maar ook verspeel kan word (Körtner 2010:52). Dit kan verspeel word deur 'n fatalistiese lewenshouding wat die noodlotsgedagte tot lewensprinsiep verhef.? Die Christelike geloof is die teenpool van die filosofie en godsdiens wat die noodlot tot kerngedagte van die lewensgevoel maak. Die tradisionele Afrikagodsdiens(te) is na my mening fatalisties van aard (vgl. Magesa [1997] 1998; Nürnberger 2007; Sundermeier [1988] 1990). Die oorheersende gevoel dat die lewe deur die noodlot (of die toedeling van die onvoorspelbare voorvaders) beheer word, het die konsekwensie dat mense besluitneming en verantwoordelikheidsaanvaarding ontduik. Wanneer geglo word dat die lewe deur groter magte beheer word en dat die individuele mens hieraan uitgelewer is, vorder niks nie; niks word met daadkrag aangepak en afgehandel nie, omdat die lewe deur vrees oorheers word - die vrees dat die noodlot die planne van die gemeente of die ring uiteindelik gaan kelder. Bultmann kan, na my mening, 'n bevrydende invloed hê op diegene wat beheers word deur die groot magte van die geesteswêreld soos die toorn van die voorvaders en die lojaliteit aan die voorvaderlike tradisie.

Ons moet natuurlik nie die fout maak om te dink dat die vrees vir besluitneming en daadwerklike optrede net binne die ruimte van die 'Afrika-kerke' aangetref word nie. Ook in die 'tradisionele susterskerke' (en binne die geledere van die Afrikaanse gemeenskap) sukkel ons met besluiteloosheid en die traagheid om te handel. Wanneer mense oortuig is dat hulle gevangenes van die verlede en/of omstandighede is, ontbreek die vryheid en die moed om uit die gevangenis te stap. Bultmann se verstaan van vryheid as 'beslissing' en

7.Fischer 2008 bied 'n omvangryke oorsig oor die begrip 'noodlot' in die teologie, filosofie en letterkunde. Steinvorth (1987:1-33) herinner aan die stryd wat vanaf Plato tot by die Renaissance gevoer is om die Europese mens van die magte van die noodlot en fatalisme te bevry. ' $n$ Terugval in die tydperk vóór Plato, beteken ' $n$ terugval in die 'primitiwiteit'. 
'besluit' kan mense (ook gelowige kerkmense) bevry uit die traagheid wat die noodlotsgeloof meebring.

\section{Aanvullend}

'n Mens kan vandag, terugskouend, nie negatief oor hierdie spesifieke artikel oordeel nie. Daar kan hoogstens gewys word op die gevaar van 'n artikel wat nie vir ons vandag, in hierdie land, geskryf is nie. Die gevaar is dat ons nie besef dat 'n artikel wat 62 jaar oud is, uiters relevant is nie. Afrikaanssprekendes wat nog nie besef dat ons nie op die staat kan staatmaak vir oorlewing nie, móét Bultmann lees. Zoeloesprekendes wat nog nie besef dat Christene vry staan teenoor die staat en die tradisionele magstrukture nie, moet eweneens Bultmann lees.

\section{Die gedagte van vryheid volgens antieke en Christelike verstaan (1959)}

Die sin van historiese arbeid bestaan nie daarin om 'n beeld van die verlede te probeer rekonstrueer, of om goeie lesse vir die toekoms daaruit af te lei nie, maar om iets aangaande 'menslike selfverstaan' daaruit af te lei wat die groeibodem is van menslike handeling (Bultmann [1959] 1975:42). Bultmann vergelyk die antieke en Christelike verstaan van vryheid met die vraag in gedagte: Watter tekste help ons om tot ' $n$ beter verstaan van menswees te kom?

Om die verskil in menslike selfverstaan te verduidelik, begin Bultmann ([1959] 1975:43) met die menings van die filosoof Anaxagoras. Op die vraag hoekom dit beter is om gebore te wees as om nie gebore te wees nie, sê hy: "n Mens is gebore om die hemel en die kosmos omvattende orde te aanskou'. Hy sê ook: 'Die doel van die lewe is die aanskoue [Schau Theoria] en die vryheid wat daaruit voortvloei.' Op grond van hierdie twee uitsprake kan twee afleidings gemaak word: (1) Die eintlike wese van die mens lê in die gees of die selfmagtige rede (Vernunft), wat die harmonieuse eenheid van die kosmos kan ken. (2) Die mens verstaan homself as deel van die kosmos; ingevoeg binne hierdie harmoniese beddings.

Die Christelike verstaan van menswees is totaal anders. Ons (Bultmann [1959] 1975:43) sien die mens nie in sy organiese plek in die wetmatig geordende kosmos nie, maar in sy staanplek in die geskiedenis. Sy eintlike wese is te vind in sy wil en kennis, en hou verband met sy verantwoordelikheid vir die geskiedenis (wat verlede en toekoms insluit). Hierdie verstaan van die 'geskiedenislikheid' (Geschichtlichkeit) van die mens is vir die Antieke vreemd. Ten spyte van die feit dat Geskiedenis as wetenskap in Griekeland ontstaan het, is die tevoorskyntrede van iets nuut binne hierdie denke nie moontlik nie. Dieselfde kan net in ander konstellasies na vore tree.

Jesus self het die woord 'vryheid' nooit gebruik nie. Paulus het hierdie woord uit die Hellenistiese spraakgebruik in die Bybel gebring. Binne die Griekse filosofie het die woord 'vryheid' veelvoudige betekenisse gehad. Naas dit wat reeds gestel is, ook die volgende: Vanselfsprekend is die woord gebruik om die posisie van die slaaf teenoor dié van sy eienaar te beskryf. Dit is ook gebruik om die bestaan van die burger binne die stad te beskryf. Om deel te wees van die stadsgemeenskap, beteken om vry te wees. Die stad is daarom beskryf as die 'gemeenskap van die vryes.' Hierdie 'politieke vryheid' word gekenmerk deur 'n dialektiek. Die vryheid van die burgers is nie subjektiewe willekeurigheid nie, maar is gebonde aan die wet(te) van die gemeenskap trouens, hulle bestaan is in die wet begrond aangesien die reg hulle vryheid beskerm. Aan die ander kant is die burgers verantwoordelik vir die reg. Hulle vryheid moet aangewend word tot die welwese van die geheel. Volgens Bultmann ([1959] 1975:44) kom alles daarop neer dat die Griek sy vryheid op grond van wetsonderhouding verkry - of in roem en verheuging in die idee van die goeie wat hyself vasstel ([1959] 1975:45). Die antieke mens maak staat op die krag van die rede. Hy glo dat hy, in die vryheid om sy rede te gebruik, die wet van die wêreld sal ontdek - wat identies is met die wet in homself. Vryheid is daarom 'n kwaliteit van menswees wat hy, ontdekkend deur die rede, bevestigend omarm ([1959] 1975:46). Die probleem van die wilsvryheid kom daarom ook nie in hierdie denke ter sprake nie, aangesien die wil altyd goed is en net die goeie kan bedink en doen. Die boosheid geskied deur dwaling en kortsigtigheid van die rede. Die bose kan deur opvoeding in 'redelikheid' oorkom word. 'Sonde' beteken binne hierdie denke om 'die doel te mis' - en die doel word gemis op grond van dwaling deur die rede ([1959] 1975:47). Bultmann ([1959] 1975:47) wys dan daarop dat hierdie tipe denke, hier en daar, heel Paulinies klink. Hy meen dat tekste soos Romeine 7:15, 1 Korintiërs 3:22; 6:12 dalk selfs deur die Stoïsynse filosofie beïnvloed kan wees. Bultmann is egter' $n$ Christelike teoloog en wys daarop dat daar fundamentele verskille tussen Paulus en die Stoa bestaan.

Volgens Paulus (Bultmann [1959] 1975:47-49) bestaan die wese van die mens nie in sy kennende rede nie, maar in sy wil wat van hom maak wat hy is. Deur ons besluite (Entscheidungen), en wel die geskiedenis van ons besluite, word ons menswees voltrek. Ons menswees is daarom nie iets wat reeds voltrek is nie, dit moet in die toekoms weer en weer voltrek word. Vryheid is daarom nie 'n kwaliteit van voorhande menswees nie, maar 'n moontlikheid wat telkens verwesenlik kan word. Vryheid is ook nie 'n hang aan die verlede nie. Die vryheid wat uit die verlede tot aansyn kom, is relatief. Volledige vryheid is vryheid van die verlede - en dit beteken vryheid van jouself (soos wat dit histories gestalte gekry het). Hierdie vasklou aan die verlede is volgens Paulus die begeerte om nie volledig vry te wees nie, aangesien volledige vryheid neerkom op 'n totale prysgawe van jouself - die wete dat jy jouself vind deur jouself te verloor. Hierdie lewenshouding open die gelowige vir wat na hom toe kom (naamlik dít wat God aan hom skenk).

Om oop te wees vir dit wat op ons afkom, beteken om van jouself afstand te doen, en om jouself in die toekoms as geskenk te ontvang. Slegs hierdie openheid is vryheid, slegs binne hierdie 
ruimte kan daar telkens 'n egte vrye beslissing gemaak word. ${ }^{8}$ (Bultmann [1959] 1975:49; my vertaling)

Volgens Bultmann ([1959] 1975:49) is dit vir Paulus duidelik wát die mens van sy verlede kan bevry: Dit is God se genade van vergewing in Christus Jesus. Hierdie genade, die vergewing van sondes, kan net telkens nuut geskenk en aanvaar word. Dit is nie ' $n$ kwaliteit van die geloof nie; dit is daarom nie iets wat die mens kan besit nie - vergewing kan slegs weer en weer in die geloof aanvaar word. Teen die agtergrond van hierdie argument is dit duidelik hoekom Paulus geloof as vryheid van die wet beskou (Rom 6:14; 10:4). Geloof, as vryheid, maak gehoorsaamheid aan die diepste intensie van die wet, naamlik liefde tot die naaste, eers moontlik. Eers wanneer jy van jouself bevry is, kan jy jou tot die naaste toewend. Eers wanneer jy jouself nie hoef te bewys nie, kan jy werklik op jou naaste gerig wees. Dit bring Paulus natuurlik uit by sy paradoksale uitspraak dat die mens slegs in gehoorsaamheid aan die wet (Rom 6:18-22; Gal 6:2), dit is in knegskap onder God se wil, vry kan wees.

Van politieke vryheid, die vryheid van die stadburger, praat die Nuwe Testament nie. Wat egter begryp moet word, is dat die Nuwe Testament (volgens Bultmann [1959] 1975:51) ons egter nie uit hierdie wêreld roep nie. Gelowiges wat uit die genade lewe, het 'n plig teenoor die medemens - hier, konkreet op hierdie aarde.

\section{Kritiese waardering Positief}

In navolging van Jesus stel Bultmann dat vryheid ten diepste vryheid van jouself is. Hierdie 'self' het egter deur die loop van jare op 'n bepaalde wyse gestalte gekry. Bultmann waarsku dat die hang aan die verlede vryheid kan verspeel. Om jou menswees nét vanuit die dinge van jou jonger jare te verstaan, impliseer 'n verlies aan vryheid vandag. Vrye menswees is gerig op gestaltegewing aan die lewe in die hede. Wie 'n gevangene van die verlede is, kan nie verantwoordelikheid neem vir vandag nie. Vryheid beteken vir Bultmann om vandag te lewe met die moontlikhede wat die toekoms bied.

Die kerklike krisis (vgl. Van Wyk 2011) van die Nederduitsch Hervormde Kerk van Afrika (NHKA) het in 'n groot mate met die gevangeskap in die verlede te make. Ou besluite moet gehandhaaf word, die ou Bybelvertaling mag nie vernuwe word nie, die kos van die voorvaders moet op 'n kermis voorgesit word, ons moet aantrek soos ons oumas en oupas en wanneer ons dít doen, 'staan ons vas in die geloof.' Geloof word só verlaag tot ' $n$ houding - 'n houding jeens die verlede. 'n Waarderende houding ten opsigte van die opbrengs van die verlede is 'n goeie menslike deug. Met die geloof in Jesus Christus, die verlosser uit die las van die verlede, het dit nog niks te make nie. Bultmann kan ons help om krities na ons eie

8.'Dem Zu-kommenden offen sein, heibt auf sich selbst verzichten, um das Selbst aus der Zukunft als Geschenk zu empfangen. Allein diese Offenheit ist die Freiheit, allein in ihr kann jeweils eine echte freie Entscheidung getroffen werden' (Bultmann [1959] 1975:49). geloofsoortuigings te kyk, met die bedoeling om opnuut vas te stel wat geloof is en wat bygeloof is.

\section{Voortbou}

Die swakheid in Bultmann se teologie het met sy oordrewe klem op die menslike beslissings te make. Vanselfsprekend word daar van gelowiges verwag om, as wesens van die vryheid, in vertroue besluite en verantwoordelikheid te neem. Openheid vir die toekoms steun egter nie net op die menslike beslissings nie. Die Christen leef ook met hoop. Sy hoop is gegrond in die handelinge van die 'God van hoop' (vgl. Pannenberg [1967] 1971 en Sauter 1995:119-161 vir ' $n$ volledige uiteensetting van hierdie begrip). God laat ons geleenthede en toestande toeval - wat dikwels niks met menslike besluitneming te make het nie. Nuwe dinge is moontlik in hierdie wêreld. Die werklikheid bestaan nie nét uit 'n eindelose herhaling van dieselfde dinge nie. Die onverwagte kom ook onverwags in ons wêreld aan omdat die Drie-enige God 'n lewende God is wat die nuwe (novum) aan ons kan skenk (vgl. Moltmann 1995:44-47 se kritiek op Bultmann). Om hierdie rede dink en besluit die Christen nie net nie, hy bid ook en verheug hom oor die goeie dinge wat God hom laat toeval (vgl. Moltmann 2014 se nuwe boek vir insiggewende perspektiewe oor hoop, vreugde en gebed).

\section{Erkenning Mededingende belange}

Die outeur verklaar hiermee dat hy geen finansiële of persoonlike verbintenis het met enige party wat hom nadelig of voordelig kon beïnvloed het in die skryf van hierdie artikel nie.

\section{Literatuurverwysings}

Baruzzi, A., 1993, Die Zukunft der Freiheit, Wissenschaftliche Buchgesellschaft, Darmstadt.

Bayer, O., 1995, Freiheit als Antwort: Zur theologischen Ethik, Mohr Siebeck, Tübingen. Bultmann, R., [1952] 1968a, 'Die Bedeutung des Gedanken der Freiheit für die abendländische Kultur', in Glauben und Verstehen: Gesammelte Aufsätze 2. Bd., 5. erw. Aufl., pp. 274-293, Mohr Siebeck, Tübingen.

Bultmann, R., [1948] [1952] 1968b, 'Gnade und Freiheit', in Glauben und Verstehen Gesammelte Aufsätze, 2. Bd., 5. erw. Aufl., pp. 149-161, Mohr Siebeck, Tübingen.

Bultmann, R., [1959] 1975, 'Der Gedanke der Freiheit nach antikem und christlichem Verständnis', in Glauben und Verstehen: Gesammelte Aufsätze, 4. Bd., 3. Aufl., pp. 42-51, Mohr Siebeck, Tübingen.

Fischer, K., 2008, Schicksal in Theologie und Philosophie, Wissenschaftliche Buchgesellschaft, Darmstadt.

Hammann, K., [2009] 2012, Rudolf Bultmann: Eine Biographie, 3. Aufl., Mohr Siebeck, Tübingen.

Huber, W., 2007, Im Geist der Freiheit: Für eine Ökumene der Profile, Herder, Freiburg.

Jüngel, E., 1990, 'Leben aus Gerechtigkeit. Gottes Handeln - menschliches Tun', in Wertlose Wahrheit: Zur Identität und Relevanz des christlichen Glaubens. Theologische Erörterungen, Bd. 3, pp. 346-364, Kaiser, München. (Beiträge zur evangelischen Theologie, 107)

Jüngel, E., [1998] 1999, Das Evangelium von der Rechtfertigung des Gottlosen als Zentrum des christlichen Glaubens: Eine theologische Studie in ökumenischer Absicht, 3., verbesserte Aufl., Mohr Siebeck, Tübingen.

Jüngel, E., [1978] 2000, 'Zur Freiheit eines Christenmenschen. Eine Erinnerung an Luthers Schrift', in Indikative der Gnade - Imperative der Freiheit. Theologische Erörterungen IV, pp. 84-160, Mohr Siebeck, Tübingen.

Körtner, U., 2010, Reformatorische Theologie im 21. Jahrhundert, Theologischer Verlag, Zürich. (Theologische Studien, Neue Folge, Bd. 1).

Laube, M., 2012, 'Tätige Freiheit: Zur Aktualität des reformierten Freiheitsverständnisses', Zeitschrift für Theologie und Kirche 109(3), 337-359. $\mathrm{http}: / / \mathrm{dx}$.doi.org/10.1628/004435412802644049

Lohse, E., 1974, 'Rudolf Bultmann als lutherischer Theologe. Zum 90. Geburtstag des Marburger Neutestamentlers am 20. August 1974', Luther 45(1), 49-54. 
Luther, M., 1520a, Tractatus de libertate Christiana, in WA 7, 49-67.

Luther, M., [1520b] 2012, 'Von der Freiheit eines Christenmenschen', in WA 7 20-38, nuut opgeneem in Martin Luther, Deutsch - Deutsche Studienausgabe, Bd. 1, Glaube und Leben, Herausgegeben von D. Korch, pp. 277-315, Evangelische Verlagsanstalt, Leipzig.

Luther, M., 1883-1993, Weimarer Ausgabe (WA): D. Martin Luthers Werke: Kritische Gesamtausgabe, 65 vol., H Bhlau, Weimar.

Magesa, L., [1997] 1998, African Religion: The moral traditions of abundant life, Orbis Books, New York, NY.

Melanchthon, Ph., [1521] [1993] 1997, Loci Communes 1521. Lateinisch - Deutsch, Übersetzt von H. Pöhlmann, Herausgegeben vom Lutherischen Kirchenamt der VELKD, 2., durchgesehene und korrigierte Auflage, Gütersloher Verlagshaus, Gütersloh.

Melanchthon, Ph., [1553] [2002] 2010, Heubtartikel Christlicher Lere, Melanchthons deutsche Fassung seiner Loci Theologici, nach dem Autograph und dem Originaldruck von 1553 R. Jenett \& J. Schilling (Hrsg.), p. 2, aktualisierte u. ergänzte Ausg., Evangelische Verlagsanstalt, Leipzig.

Moltmann, J., 1995, Das Kommen Gottes: Christliche Eschatologie, Kaiser, München.

Moltmann, J., [1997] 1999, God for a secular society: The public relevance of theology, transl. M. Kohl, SCM, London.
Moltmann, J., 2014, Der lebendige Gott und die fülle des Lebens: Auch ein Beitrag zur Atheismusdebatte unsere Zeit, Gersloher Verlagshaus, Gütersloh.

Nürnberger, K., 2007, The living dead and the living God: Christ and the ancestors in a changing Africa, Cluster Publications, Pietermaritzburg.

Pannenberg, W., [1967] 1971, Der Gott der Hoffnung', in Grundfragen systematischer Theologie: Gesammelte Aufsätze, Bd. 1, 2. Aufl., pp. 387-398, Vandenhoeck, Göttingen.

Sauter, G., 1986, “"Freiheit” als theologische und politische Kategorie', in G. Besier \& G. Ringhausen (Hrsg.), Bekenntnis, Widerstand, Martyrium: Von Barmen 1934 bis Plötzensee 1944, pp. 148-165, Vandenhoeck, Göttingen.

Sauter, G., 1995, Einführung in die Eschatologie, Wissenschaftliche Buchgesellschaft, Darmstadt.

Steinvorth, U., 1987, Freiheitstheorien in der Philosophie der Neuzeit, Wissenschaftliche Buchgesellschaft, Darmstadt.

Sundermeier, T., [1988] 1990, Nur gemeinsam können wir leben: Das Menschenbild schwarzafrikanischer Religionen, 2. Aufl., Mohn, Gütersloh. (Gütersloher Taschenbücher Siebenstern, 784).

Van Wyk, I.W.C., 2011, 'Wat is reformatoriese teologie? Nadenke na aanleiding van 'n kerklike beswaarskrif', HTS Teologiese Studies/Theological Studies 67(3), Art.\# 1156, 11 pages. http://dx.doi.org/10.4102/hts.v67i3.1156 